\title{
The UN Security Council Permanent Membership: The Troubling Trend of Expansion and Hegemony
}

\author{
Fiemotongha Christopher, Nein Godknows, Isaac E. Uki, Ogbotubo L. Seaman, Edoni H. Harcourt \\ Department of Political Science, Isaac Jasper Boro College of Education Sagbama, Bayelsa State, Nigeria \\ Email: christofiems@gmail.com, godknowsnein@gmail.com
}

How to cite this paper: Christopher, F., Godknows, N., Uki, I. E., Seaman, O. L., \& Harcourt, E. H. (2021). The UN Security Council Permanent Membership: The Troubling Trend of Expansion and Hegemony. Open Journal of Political Science, 11, 316327.

https://doi.org/10.4236/ojps.2021.112021

Received: June 28, 2020

Accepted: April 22, 2021

Published: April 25, 2021

Copyright $\odot 2021$ by author(s) and Scientific Research Publishing Inc. This work is licensed under the Creative Commons Attribution International License (CC BY 4.0).

http://creativecommons.org/licenses/by/4.0/ (c) (i) Open Access

\begin{abstract}
The paper is on the UN Security Council (UNSC) permanent membership: The troubling trend of expansion and hegemony. The problem of UN Security Council, which is an exclusive nuclear club, whose powers are unchecked, with lack of true international representation and with powers to veto, is the dominance of the permanent members. The main objective of the study is to investigate an overview of the United Nations Security Council (UNSC) permanent membership and examine the Troubling Trend of hegemony and the problem of expansion. The methodology is basically a qualitative and exploratory method, using text, newspapers. The study employs power politics theory as a tool for analysis. One major finding amongst others is that, there is a global hegemony of the permanent members of the Security Council. The permanent members block other member states of the UN, who seeks expansion or vies for permanent seat, through their powers of veto. This paper recommends the expansion of the United Nations Security Council (UNSC) permanent membership to include Africa and other power centres for fair representation in the United Nations Security Council (UNSC).
\end{abstract}

\section{Keywords}

Expansion, Hegemony, Permanent Membership, Security Council, UN, Veto Power

\section{Introduction}

The paper is on the UN Security Council permanent membership, the need for expansion; the troubling trend of the security council is hegemony. The United Nations charter was signed at a conference in San Francisco in June, 1945, led by four countries: Britain, China, the Soviet Union and the United States. After 
fierce negotiations, 50 nations agreed to the charter that begins (Somini, 2019).

When the charter went into effect on October, 24 of that year, a global war had just ended. Much of Africa and Asia was still ruled by colonial powers. Why is that opening notable? Because today, the United Nations can, to some seem to serve the narrow national interest of its 193 members countries especially the most powerful ones and not ordinary citizens. These parochial priorities can stand in the way of fulfilling the first two pledges of the charter: to end "the scourge of war" and to regain "faith in fundamental human rights" (Somini, 2019).

In principle, nations, states small or large, rich and poor, have equal voice in the General Assembly with each country getting one vote. But the genuine power resides elsewhere. The 15-member Security Council is by far the most powerful arm of the United Nations. It can impose sanctions, as it did against Iran over its nuclear program, and authorize military intervention, as it did against Libya in 2011 (Somini, 2019).

According to Somini (2019), this is the most anachronistic part of the organization. Its five permanent members are the victors of World War II: the United States, Britain, China, France, and Russia. The other 10 members are elected for two-years terms, with seal set aside for different regions of the world. Effort to expand the permanent members of the Council to include powers that have emerged since 1945 such as India, Japan and Germany-have been stymied. For every country that vies for a seal, rivals seek to block it. Since inception, any member of the permanent five or the P5, for short-cam veto any measure, and each has regularly used this power to protect either itself or allies. In the 1990, the United States has cast a veto on council resolutions 16 times, including eight times over Syria. However, in theory, the charter does allow the General Assembly to act, if because of a veto, international peace and security are threatened. But in reality, it is rarely done.

The Security Council's job is to maintain international peace. Its ability to do so has been severely constrained in recent years, in large part because of bitter division between Russia and the West. The Council has been feckless in the face of major conflicts, particularly those in which permanent members have a stake. Hence, this paper tends to poise these questions. Why is the Security Council constrained? Why is the permanent hegemony of the council. Is there no need for expansion? These and other questions require answer.

Since its functioning, there have been many calls for reform of the UN but little consensus on how to do so. Some want the UN to play a greater or more effective role in world affairs, while others want its roles redeemed to humanitarian work. There have also been numerous calls for the UN Security Council's membership to be increased for different way of electing the UN's Secretary. General and for a UN Parliamentary Assembly (Kennedy, 2007).

\section{An Overview of the United Nations}

The formation of the United Nations became necessary, owing to the failure of 
the League of Nations and the resultant occurrence of the Second World War. The united nation, which was formally referred to as the united nations organization U.N.O came into being at the san Francisco conference of 1945, facilitated by the allied forces. The San Francisco Conference was a follow-up of the Dumberton Oaks Conference of 1944 including representatives of the Big Four (The United States, Great Britain, the USSR and China), which laid the foundation for the structures of the U.N.O (Gilbert \& Tom Otuya, 2005). At this conference of San Francisco, the united nations charter as well as laws of the new international court of justice (I.C.J) were signed, with all the representatives to the conference signing the charter on 26th June 1945 which came into being in October 1945 Edmund (2006). Though formed with aims and objectives, the United Nations, has since transcended its traditional role of prevention of war, maintenance of international peace and security, including providing succour for countries defeated in war which could be traced to the inability of the League of Nations to guarantee international peace and security. During its early years, the UN's emphasis was on security, however this concern has not abated, but it has been joined, by social economic, environmental and other non-military security concerns (Rourke \& Boyer, 2000; Nwibor, 2014).

The United Nations is the most encompassing international organization, with a global membership that is open to all sovereign states of the world, who are ready to share in its ideas and abide by the charter establishing it. The United Nations has organs which includes, the Security Council (with five permanent members-China, Russia, France, Britain and the United States and ten non permanent members elected for a period of years). The General Assembly, Economic and Social Council, the Trusteeships council, the international court of justice and the secretariat. Each of the five permanent members has a power of veto, this means that if any of the five opposes a matter on which a vote is being taken the matter is dropped even if all others support it (Ndoh, 2003). However, the way manner the United Nations operates has attracted Scholarly Criticisms, and from members state including the constitution of its organs. Unarguably, it has been adjudged to have recorded some remarkable achievements, but has also being criticized for been undemocratic and dominated by the powerful countries that occupy the permanent membership position in the Security Council, with the exercise of veto. The Security Council and especially the five permanent members, were given special powers and responsibility, meanwhile, the veto Power granted "The Big Five" (USA, Britain, Russia, France and China) soon became the body's Achilles heels (Assan \& Fatai, 2013). This is even made worse by the rivalry between the East and the West, in a bid to further communist and capitalist agendas. As contained in its preamble, the United Nations compliments its function of maintenance of international peace and security, with the promotion of economic and social advancement of all member states, which could be done through the promotion of human rights, pursuit of socio economic progress, promotion of technical cooperation etc. 
No doubt, the General assembly of the United Nations provides for equal representation of all member states and equal voting rights, but its deliberations and decisions are subjected to the highest decision making body of the organization, which is the security council

\section{Composition of the Security Council}

The security council is the highest decision making organ of the United nations saddled with the utmost responsibility of maintaining international peace and security, Though the permanent membership of the organization has not been altered from its inception, the present structure was brought to bear after the amendment of the charter in 1965, bringing the non-permanent members to ten which was implemented on January 1 1996. The distribution of the non-permanent members allocates two seats to Latin American states, three to Africa, three to European states and two to Asia.

Now the Security Council has the fixed membership of fifteen of whom five are permanent members (USA, Britain, Russia, China and France) and the remaining ten are non-permanent members elected for Two years (Agarwal, 2006). As stated in article 23 (1) of the UN charter, the General Assembly elects ten non-permanent members to the Security Council with regard to contribution of member states of the UN to maintenance of international peace and security and consideration of geographical distribution.

The Security Council has fifteen members, but there is inequity in the distribution and exercise of powers, subjecting the interest of majority to the control of a few. As it is explicitly provided for, the consent of the ten non-permanent members is required in procedural matters. This implies that all other matters except procedural matters are left for the "big five" permanent members, who have the right to veto. The amendment in 1965 only enlarged the non-permanent membership but could not expand or make adjustment on the permanent membership of the Security Council who wield so much power. The resolution containing the amendment called for the ten non-permanent seats to be allocated by geographical areas. In fact Afro-Asian countries were not considered for permanent membership of the council, despite the presence of Egypt, Ethiopia, Liberia, and South Africa at the formation of the organization in 1945 (Obi, Ozor, \& Agary, 2008).

It is discernible, that the allied powers capitalized on their victory at the war to initiate and form an organization of a global status for the maintenance of international peace and security, but in furtherance of their interest and subjected to their dictates, hence the structuring of the security council in a manner that gives the permanent members more powers to decide issues. This motive of the permanent members is subtlety provided for in article 108 and 109 of the UN charter, which gives the permanent members the right to squash any effort to eliminate their (permanent members) veto by constitutional amendment. This dominance of the permanent members in the Security Council may not be un- 
connected to the dependence of the UN's core and peacekeeping budget on the assessment it levies member countries, where the non-permanent members pay lesser assessment. The "Targent" voluntary budget payments are the same as the core budget, and because of their special responsibility (and their special privilege, the veto), permanent UN Security Council members pay a somewhat higher assessment for peacekeeping, with the US share at 31 percent (Rourke \& Boyer, 2000). This could be interpreted as more responsibility, more privileges, which could be further construed as a dent on the sovereign equality status of member states.

\section{Theoretical Framework}

This paper employed the power politics theory to explain and analyze the importance of power in the international system and how states seek to acquire it, since there is no single sovereign authority empowered to regulate the actions and inactions of states at the international scene. The chief exponent of this theory is Hans. J. Morgenthau. One man whose name has mostly been associated with the realist school of thought in the twentieth century is Hans Morgenthau (Elemanya, 2018). The realist believes that, peace and order in the international system could be achieved through the balance of power. They argued that it is neither the existence of international law or international moralism or the process of international organization that explains the maintenance of international order and peace (Asogwa, 1999).

According to Schuman (in Obi \& Ozor, 2009) where a state possesses "sufficient power" and others lack it, it will, with utmost mathematical certainty proceed to subject them to its own authority the forms here, is the use of power, and it is only by the powerful states that count in the system. Morgenthau (1973) further emphasized that, balance of power is the inevitable and essential stabilizing factor in a society of sovereign states, as well as a general social principle to which all societies composed of a number of autonomous units owe the autonomony of their component units. Having identified "power" as a major determinant in international relations, the allied power introduced the veto power clause in the UN charter to dominate the activities of the organization. This position of the permanent members and the veto power of the Security Council were not concealed. Especially during the cold war, when they exercised their veto power to block the election and re-election of several secretaries general, perceived as not likely to protect their interest or nominated by an opposing bloc. Theoretical framework is a guide to this work and directs scholars towards the concepts employed in this research and makes it possible for easy conceptual clarification.

\section{Conceptual Clarification}

\section{1) The United Nations}

The United Nations is intergovernmental international organization that was 
established after the Second World War basically as a result of the failure of the League of Nations to prevent the occurrence of the Second World War. The UN is an intergovernmental organization that aims to maintain international peace and security, develop friendly relations among nations, achieve international corporation, and be a centre for harmonizing the actions of nation (UN Charter, Chapter I).

\section{2) Hegemony}

This is a state of affairs in international relations, where a state or group of states exercises overriding power over other states, and uses it to control the actions and inactions of states in the international system. The hegemonic state/ states enforce established rules by meting out rewards and punishment.

\section{3) Permanent Membership of the UN}

These are the members of the security council that wield veto power. the five permanent members of the Security Council are United Kingdom, United States, Russia, France and China. The permanent members of the Security Council exercises power of veto while the ten-non-permanent members do not have the right of veto.

\section{4) The Security Council}

The UN Security Council is the highest decision making body of the United Nations (UN). The Security Council has primary responsibility for the maintenance of international peace and security. Under the charter of the United Nations, all member states are obliged to comply with the unanimous decisions of the Security Council.

\section{Methodology of the Study}

The study is basically a qualitative and exploratory study as such the study relied on secondary sources of data sourced form journal, textbooks, newspapers and magazines publications as well as online materials. The contents of these materials are employed to further deepen the analysis of the issues raised in the study.

The qualitative method is employed here to allow us (researchers) to look at the specific questions. It involves collecting and analyzing non-numerical data (e.g text, video and audio) to understand concepts, opinions or experiences.

\section{Objectives of the Study}

This study is premised on the following two objectives:

1) To understand an historical overview of the United Nations Security Council permanent memberships.

2) To examine the Troubling Trend of hegemony and expansion of UN Security Council.

\section{The Exercise of "Veto"}

The exercise of veto works in different ways, the Security Council selects the Secretary-General through series of straw polls. However, a vote by a permanent 
member against a member "disqualifies" a candidate and this is equivalent to a veto. The formal recommendation of a Secretary-General is approved unanimously by acclamation. That is, to veto any "substantive" resolution. However, a permanent member's abstention or absence does not prevent a draft resolution from being adopted. This veto power does not apply to "procedural" vetoes as determined by the permanent member which can also block the selection of a Secretary-General, although a formal veto is unnecessary since the vote is taken behind closed doors (Sabastian, David, \& Bruno, 2015; John, 2018).

The exercise of veto by the permanent members of the Security Council (the highest decision making organ) distinguishes them and the Security Council from other members and organs of the United Nations. The right of veto was introduced from inception of the UN by the Allied forces (USA, Russia china, France and Britain) who initiated and championed its (UN) formation. Akindele and Bassey (2011) explains the importance of the Security Council and the right of veto, of the permanent members thus: its crucial roles and enormous powers, in fact, explain why the major victorious allied powers in 1945 imperially sponsored and pre-emptively insisted on their being its permanent members, along with the special privilege of the veto power attached to it. This position of the permanent members was further buttressed by US senator Tom Cornnally when he stated in reference to those opposed to the veto power that "they could go home from San Francisco if they wished and report that they had defeated the veto but they could also report that they had Tom up the charter". Though, the permanent and non-permanent members of the security council are all entitled to a vote each, this is only applicable to procedural matters, where a majority of the fifteen members in the security council is allowed to prevail.

The UN charter, empowers the permanent members to apply their "veto" power in every substantive matter, which means that in every real and important matter, (aside procedural matters) the decision of the permanent members will prevail, in such a way that, all five permanent members must support a matter, for it to scale through, otherwise one contrary vote from a permanent member on a substantive issue, nullifies the whole process. Thus, the Security Council members collectively have the power to block any substantive recommendation of the general Assembly by their veto, while any of the five permanent members can block any substantive decision of the Security Council by her veto. Consequently, the United Nations collective security system can only work if there is full agreement among members (Edmund, 2006). The veto provision in the Security Council has attracted criticism both from scholars and member states. The veto power provision contradicts the sovereign equality provision and is incompatible with the ethics of democracy, championed by the west as the best form of government. Though several scholarly arguments have been put forward either for expansion or replacement, of the permanent members, the provision is undemocratic and negates the essence of democracy. The clandestine motive of the veto power provision was made known by the then US Secretary of state hull, 
when he asserted that the veto principle was incorporated into it primarily on account of the united states, and with respect to the proposed security council that "our government would not remain there a day without retaining its veto power" (hull in Obi \& Ozor, 2009).

Though there has been consistent calls for the reform of the UN especially the Security Council and its veto, the permanent members and those who support the veto have also always responded to the heated debate of the reform of the Security Council, with reference to UN resolution 337. As Saleh (2018) argues, the veto and the threat of it use which has the potential to paralyze the ability of the Security Council in taking any action could be dealt with by utilizing the "uniting for peace" resolution for the purpose of fulfilling the duty of the Security Council in the maintenance of international peace and security when it fails to perform such duties.

The veto power provision does not give credence to the principles of democracy, when decision making power is disproportionately and unevenly distributed; it contradicts the sovereign equality principle of the UN charter, which is conceptually compatible with democratic ethics. Why is it that the charter recognizes the principle of majority rule on procedural matters but decline to do so on substantive matters? This alone is a clear indication of the charters intent to strategically position the "big five" for decision making of the organization. The structure and voting pattern in the Security Council flagrantly renders the principles of majority rule, popular sovereignty and political equality impotent, therefore killing the zeal of other members states, who have long registered their resentment.

\section{The Case for Expansion and Troubling Trend of Hegemony}

Several arguments and positions have been advanced by scholars and member states of the UN in a bid to correct the inequity and anomaly in relation to voting rights and permanent membership of the Security Council. Explicitly, these propositions are advanced in order to structure the international organization in such a way that truly reflects an equitable representation of all sovereign states of the world. Some scholars are of the position that, the number of permanent members currently in the security council be increased to accommodate new powers or that the seats of France and Britain be vacated for Japan, Germany or India, while others have argued that the seats of Britain and France be made available for rotation among members, like that of the non-permanent members. As Ojo and Sesay (2002) contends that the seats presently occupied by France and Britain could rotate among the prospective candidates just like the temporary members of the council, the difference being that each of the "revolving" permanent members would wield a veto while it occupies its seat at the council. Having put forward these lofty ideas for restructuring of the Security Council and for an equitable representation, the present permanent members seem not 
to be ready for any alteration of the present structure, as the argument for the expansion or adjustment of the security council intensifies. Support has been given to Germany and Japan for their inclusion in the security council, perhaps because of their economic strength and what they contribute to the UN budget.

Since economic and financial strength is an indication of the capacity to contribute to the maintenance of international peace and security, economic giants and financial superpowers like Germany and Japan are often mentioned to deserve high consideration for permanent seats in the Security Council (Akindele \& Bassey, 2011). If economic and financial strength are necessary credentials to contribute to the maintenance of international peace and security and a prerequisite to qualify for permanent membership position of the UN Security Council, then the equitable geographical distribution of seats principle should be stressed to accommodate potential members like the regions of Latin America, Africa and Asia respectively. It could be construed from examinations of various arguments in relation to the expansion or replacement of permanent members of the Security Council that, none of the permanent members would be ready to give up their position to accommodate potential permanent members of the council, due to the importance they attach to the exercise of "veto power" evident in the use of veto power in the past where the Eastern and Western blocs have used it to block perceived opposing candidates for the position of secretary general. In 1953, the Soviet Union vetoed the election of Mr. Lester person of Canada who was sponsored by the common wealth and Western Europe, the Soviet Union was confident Mr. Person would invariably enhance the course of the Western Bloc. In consequence, the Security Council gave its unanimous approval to a comprised candidate, Mr. Dag Hammarskjold who was a Swedish Foreign Minister. In November 1996 the United States also vetoed the re-election of Boutros Boutros Ghali for a second term for opposing US interest, although the US claim it was because of Ghali's failure to affect much needed reforms in the organization (Obi, Ozor, \& Agari, 2008). As at 2012, 269 vetoes had been cast since the security council's inception in this period, china used the veto 9 times, France 18, Russia 128, the UK 32 and the US 89 times. Roughly, twothird of Russian vetoes were in the first ten years of the. Security Council's existence (Security Council Reform, 2013).

Having ruled out a possible replacement for Britain and France, the option of possible expansion of the Security Council could be achieved if pursued consistently with unanimity from the regions or power centers agitating for permanent membership of the Security Council and also if renewed pressure is put on the big five from the general assembly in a way of protest.

There has been criticism that the five permanent members of the United Nations Security Council, who are all nuclear powers, have created an exclusive nuclear club whose powers are unchecked unlike the General Assembly, the United Nations Security Council does not have true international representation. This has led to accusation that UNSC only addresses the strategic interest 
and political motives of the permanent members, especially in humanitarian intervention for examples, protecting the oil-rich Kuwaitis in1991 but properly protecting resource-poor Rwanda in 1997 (Rejan, 2006).

Hence, the major criticism of the UNSC are:

1) Having nations with veto power in the council makes it difficult to pass resolutions. In 2017, the UNSC was unable to pass a resolution to investigate the use of chemical weapons in Syria because Russia used its veto. The representation of Liechtenstein also voiced his disapproval of the UNSC's inability to pass a resolution to quell the conflict in Aleppo, Syria.

2) The UNSC is not geographically inclusive. For example, none of the 5 permanent members (who hold veto power) are from the continent of South America or Africa.

\section{Findings of the Study}

It is observed in the is study that the allied powers capitalized on their victory in the Second World War to establish for themselves a global organization that will further their interests in world politics. The actualization of the aspirations of member states is thwarted, hence members countries have persistently expressed their resentment in relation to the exercise of veto and structural imbalance of the global organization. The agitation for the inclusion of new permanent members has not yielded the expected result due to lack of unanimity in the demand for permanent seats. The demand for permanent seats $b$ Africa and other power centres could be productive if the focus is on the expansion of the council, rather than the replacement of Britain and France. It is also of the findings of this study that the global organization is used as a cloak on the global agenda for democratic principles.

\section{Conclusion}

The UN security council permanent membership and the exercise of veto have attracted persistent criticism from member states and observers, but the present structure which has remained since the formation of the body in 1945 is yet to be altered. The crux of the argument has been a possible expansion of the permanent member council or a replacement of Britain and France by other potential power centers, but has not established any consensus. As could be inferred from this study, attempt to replace any of the big five will be an exercise in futility, as the allied powers deliberately accorded themselves the right of veto to dominate the universal organization and if any meaningful restructuring must be attained, the focus must be on the expansion of the security council to include potential permanent members and ensure equity in the exercise of power in the council.

\section{Recommendations}

Having highlighted the findings of this study, the paper wishes to make the following recommendations: 
1) Though the allied powers capitalized on their victory at the war to form a global organization that could be subjected to their control. They must concede to ensure restructuring of the Security Council if democracy and the principles of sovereign equality status provided for in the UN charter means anything to them, so as to avert a possible collapse of the UN like the League of Nations.

2) It is recommended in this paper that collective consistent pressure on the "big five" from member states in the form of protest in the General Assembly could yield some result.

3) The quest for a seat in the Security Council by member states must be enforced with unanimity from the regions or continents they come from, otherwise multiple demands will only amount to a repetition of failed attempts in the past.

4) The demand for permanent membership seats in the Security Council and the suggestions so far made should be narrowed to the feasible option of expanding the council to accommodate potential members, rather than demanding for the replacement of Britain and France. Who seem not ready to compromise their position in the council?

\section{Conflicts of Interest}

The authors declare no conflicts of interest regarding the publication of this paper.

\section{References}

Agarwal, R. C. (2006). Political Theory Principles of Political Science. New Delhi: Chand and Company Ltd.

Akindele, R. A., \& Bassey, E. A. (2011). Selected Readings on Nigeria's Foreign Policy and International Relations. Ibadan: Vintage Publishers.

Asogwa, F. C. (1999). Understanding International Relations. Enugu: Vougasen Ltd.

Assan, A. S., \& Fatai, A. A. (2013). Introduction to International Relations. Ibadan: College Press and Publishers Ltd.

Edmund, E. O. (2006). The Web of International Politics. Analysing International Relations. Onitsha: Chambers Books Ltd.

Elemanya, A. V. (2018). Introduction to Security and Strategic Studies. Port Harcourt: Emmanest Venture.

Gilbert, L. D., \& Tom Otuya, B. E. N. (2005). Themes in Western European Foreign Policies. Port Harcourt: NISSI Books.

John, L. (2018). The Role of Non-Permanent Members on the United Nation Security Council. The Case of Sweden, 2017, Malmo University, International Relations Depth of Global Political Science.

Kennedy, P. (2007). The Parliament of Man: The Past, Present and Future of the United Nation. New York: Random House.

Morgenthau, H. (1973). Politics among Nations. New York: KNOPF.

Ndoh, C. A. (2003). An Introduction to Political Science.

Nwibor, L. B. (2014). The Security Council and Global Peace, "Issues and Challenges". Journal of Humanities and Social Sciences, 19, 47-51.

https://doi.org/10.9790/0837-19834751 
Obi, C. A., \& Ozor, C. O. (2009). The Process of International Relations. Theories, Processes and Institutions. Onitsha: BookPoint Educational Ltd.

Obi, E. A., Ozor, C. O., \& Agari, N. N. (2008). International Organizations and Institutions. Onitsha: BookPoint Educational Ltd.

Ojo, O., \& Sessay, A. (2002). Concept in International Relations. Iie Ife: Obafemi Awolowo University Press Ltd.

Rejan, C. (2006). Global Politics Sand Institutions. Archived from the Original (PJF) on January 21, 2012 (449 kg) Frontier of a Great Transitor, vol. 3 Tellus Institute P. 3.

Rourke, J. T., \& Boyor, M. A. (2000). World Politics. International Politics on the World Stage. New York: McGraw-Hill/Dushkin.

Sabastian, V. E., David, M. M., \& Bruno, S. U. (2015). The UN Security Council in an Age of Great Power Rivalry. United Nations University, Working Power Series.

Saleh, A. (2018). The Security Council's Veto in the Balance. Journal of Law, Policy and Globalization, 58, 135-145.

Security Council Reform (2013). Global Policy Forum.

Somini, S. (2019). The United Nations Explained: Its Purpose, Power and Problems. The New York Times, Sept. 17.

UN Charter, Chapter I.

https://web.archive.org/web/20150712155312 